\section{Nuclear wastes seek home}

\section{London}

WHAT is to happen to nuclear waste in Eastern and Central Europe? Nuclear plant operators there must decide very soon what to do with accumulating wastes now that the civil atomic power authorities of the former Soviet Union can no longer handle them.

Nuclear wastes generated by the Soviet-designed reactors used to be taken back to the Soviet Union, free of charge, for reprocessing. But a few years ago the Soviet government began to charge for this service. Late last year, the authorities announced that they would no longer accept any shipments.

Mr Hans Blix, director-general of the UN International Atomic Energy Agency (IAEA) in Vienna, has offered to mobilize help for the republics joining the postSoviet Commonwealth of Independent States. At the same time, Sweden is helping Lithuania to set up an independent nuclear power authority, British Nuclear Fuels and France's Cogema are negotiating with East European governments while contractors from Western Europe, the United States and Canada are seeking business in the region.

The arrangements made for handling spent fuel may determine the fate of the 62 largely obsolete Soviet-designed nuclear power plants, 17 of which are in the new Eastern and Central European democracies. A recent IAEA study described some of them as being in a dangerous condition.

A quarter of the electricity consumed in the territories west of the Urals is nuclear. The IAEA is concerned that, in the absence of a central regulatory authority, individual plant operators will be asked to shoulder too much responsibility for safety standards. Given the increased demand for nuclear electricity caused by acute shortages of other fuels and the already heavy economic and political stresses on the system, IAEA officials fear that such an approach is an invitation for disaster.

That there is chaos in the ex-Soviet nuclear power industry has been evident since the German Environment Minister, Klaus Toepfer, was told in Moscow late in October that the country simply lacked the means to take back spent fuel, contractual obligations notwithstanding.

Germany, Czechoslovakia and Bulgaria, saddled with the most dangerous Soviet-built reactors outside the commonwealth, as well as Hungary, must therefore find other solutions. Toepfer wants a joint Western approach to this huge problem. But a piecemeal approach seems more likely. Czechoslovakia, Bulgaria and Hungary are expected separately to announce plans to build new dry storage facilities to house spent fuel for up to 50 years.

Germany has closed down the notorious Soviet-built Greifswald nuclear plant, consigning its spare parts to the Kozloduy plant in northern Bulgaria. That plant was also condemned by the IAEA study because of its shoddy safety equipment and frequent radiation leaks. The makeshift waste-storage facilities near the Bulgarian plant on the Danube are also dangerous and, in any case, are likely to be full in a matter of months.

Czechoslovakia, whose Bohunice plant was also condemned by the IAEA study as well as by safety investigators from neighbouring Austria, is also storing spent nuclear fuel near the reactors in unsafe conditions, according to an unpublished report commissioned by Greenpeace, the environment pressure group. The concrete used in the construction is said not to be waterproof, while the storage tanks were not designed for long-term use.

In Hungary, the technology, infrastructure and safety culture of its Paks nuclear power complex are highly regarded by IAEA. But the country's temporary waste storage facilities were judged to be inadequate. Some observers expect Hungary to embark on nuclear power generation for export to neighbouring Austria and Italy, countries that have set their faces against operating nuclear plants.

Thomas Land

\section{Environment project in Poland}

THE first project to be financed from the $\$ 1,400$ million Global Environment Facility (GEF) is aimed at rescuing and upgrading vast forest lands in Eastern Europe affected by environmental pollution, including the infamous Black Triangle where Poland, Czechoslovakia and the eastern part of Germany meet. GEF is a new programme managed by the World Bank and financed largely by the industrialized countries of Western Europe, the United States and Japan.

Established at a Paris conference in November 1990, the fund is a three-year pilot programme providing grants and lowinterest loans to poor countries (with a per capita gross national product beneath $\$ 4,000$ a year) to enable them to relieve pressures on global ecosystems.

The initial \$4.5 million grant financed by GEF will support Poland's efforts to protect its endangered forest ecosystems. The project includes plans for preserving woodlands, flora and fauna in the Sudety Mountains in the south-western part of the country as well as the Bialowieza Primeval Forest in the east.

The Sudety Mountains are in the centre of the ecological disaster area known as the Black Triangle, where 13,000 hectares of forests in the Karkonosze region are dead and another 8,000 dying because of air pollution. The damage area is expanding eastwards.

About 58,000 hectares of the ecologically fragile Bialowieza forest are in Poland and the remaining 87,000 hectares in Byelorussia. This is Europe's largest expanse of natural forest, home of the European bison, lynx, wolf and the black stork.

The GEF programme in Poland and a tentatively agreed $\$ 1 \mathrm{~m}$ companion project proposed for Byelorussia will partly finance the construction of a gene bank, a greenhouse, seed orchards and equipment for collecting plants and seeds and monitoring air and soil quality as well as land use patterns. The grant will also provide specialist training and promote sound management and sustainable forest development policies.

The GEF programme is based on the recognition by industrialized countries that they must assist the developing countries in their efforts to sustain fragile ecosystems. Countries applying for GEF funds must be party to the Montreal protocol which restricts the production of substances which deplete the ozone layer.

The fund has selected four areas for principal support:

- Biodiversity: The richest remaining sources of ecological systems and diversity of species are in the developing countries;

- The ozone layer: Developing countries will be assisted in making the transition from the use and production of chlorofluorocarbons and other gases which contribute to ozone depletion;

- Greenhouse-gas emissions: The adoption of cleaner fuels and technologies in the energy, agriculture and industry sectors.

- International waters: Investment for contingency programmes to prevent marine oil spills. GEF will contribute towards improved reception facilities for the removal of ballast water from oil tankers in ports and finance programmes to prevent or clean up the pollution of major waterways.

"If poor countries are to play their part in preventing further climate change and saving species, they will need special practical help", says Lynda Chalker, the British Minister of Overseas Development. "GEF should be strengthened and reinforced to provide the third world with the means to tackle global environmental problems."

Thomas Land 